\title{
Fluctuations in serological hepatitis C virus levels in HIV patients
}

\author{
Vanessa Cristina Martins Silva ${ }^{[1]}$, Samira Julien Calux ${ }^{[1]}$, Marcilio Figueiredo Lemos ${ }^{[1]}$, \\ Adriana Parise Compri ${ }^{[1]}$, Ana Paula de Torres Santos ${ }^{[2]}$, Isabel Takano Oba ${ }^{[1]}$, \\ Maria Cássia Jacintho Mendes-Correa ${ }^{[3]}$ and Regina Célia Moreira ${ }^{[1]}$
}

[1]. Laboratório de Hepatites Virais, Centro de Virologia, Instituto Adolfo Lutz, São Paulo, SP, Brasil.

[2]. Laboratório de Imunologia, Hospital das Clínicas, Universidade de São Paulo, São Paulo, SP, Brasil.

[3]. Departamento de Doenças Infecciosas, Universidade de São Paulo, São Paulo, SP, Brasil.

\begin{abstract}
Introduction: Hepatitis $\mathrm{C}$ virus (HCV) and human immunodeficiency virus (HIV) have identical transmission routes, explaining the high prevalence of coinfections. The main aim of this study was to detect fluctuations in serological HCV levels in HIV patients. Methods: We analyzed samples of 147 patients who attended an outpatient service that supports HIV/AIDS patients in São Paulo city. We also recruited $22 \mathrm{HCV}$-monoinfected patients who attended the Instituto Adolfo Lutz Laboratory in São Paulo city, to compare the test results. Serological testing of the blood samples was performed for the detection of HCV antibodies. The samples were then analyzed using real-time PCR for RNA viral quantification and sequencing. Results: We found that $13.6 \%$ of the study population was coinfected with HIV and HCV. In $20 \%$ of coinfected patients, fluctuations in serology results were detected in samples collected during the follow-up. No changes in anti-HCV serological markers were observed in HCV-monoinfected patients. An HCV viral load was detected in 9,5\% of the samples collected from HIV patients. Conclusions: Our findings provide important clinical data to public health professionals and highlight the importance of periodic monitoring of $\mathrm{HCV} / \mathrm{HIV}$ coinfected patients.
\end{abstract}

Keywords: Fluctuation. Hepatitis C virus. Serology. Human immunodeficiency virus.

\section{INTRODUCTION}

Hepatitis $\mathrm{C}$ virus (HCV) infection is one of the leading causes of chronic liver disease worldwide and can lead to cirrhosis, liver failure, and/or cellular hepatocarcinoma ${ }^{1}$.

About 71 million individuals with chronic HCV infection are at risk of developing disease complications worldwide ${ }^{2}$. Brazil is considered a country of intermediate endemicity for hepatitis $\mathrm{C}$. In an epidemiological study conducted in all 5 macro-regions of Brazil and the federal district, the prevalence of $\mathrm{HCV}$ antibodies was $1.38(95 \% \text { confidence interval [CI] } 1.12 \%-1.64 \%)^{3}$.

The risk for HCV infection has been increasing among the most vulnerable population groups, including illicit drug users, patients who participated in blood transfusions before 1993, and individuals with other forms of percutaneous exposure such as tattoos, piercings, dental procedures, or manicures/pedicures ${ }^{4}$.

In Brazil, approximately $0.5 \%$ of the adult population is living with HIV. Among individuals attending public health

Corresponding author: $\mathrm{Dr}^{\mathrm{a}}$ Regina Célia Moreira.

e-mail: regina.moreira7@gmail.com

Received 8 June 2018

Accepted 31 August 2018 services for outpatient care, $16 \%$ were shown to be coinfected with $\mathrm{HCV}^{5}$. Among the hepatitis-confirmed cases, from 2007 to $2016,9.8 \%$ had HIV coinfection. Among the Brazilian regions, the highest rate of $\mathrm{HIV} / \mathrm{HCV}$ coinfected individuals was observed in the Southern region, with $13.2 \%$ of the total cases of hepatitis $\mathrm{C}^{6}$. Moreover, $42 \%$ of individuals attending the Centers for Testing and Counseling and 54\% of those attending infectious disease clinics were coinfected with HIV and HCV 5 .

Since HIV/HCV coinfection has great epidemiological importance, the present study attempted to diagnose $\mathrm{HCV}$ in HIV patients.

\section{METHODS}

\section{Patients}

Sampling, by convenience, was done in HIV patients randomly recruited from 169 appointments. These patients attended an outpatient service that supports HIV/AIDS (SEAP) patients at the Department of Infectious Diseases, Faculty of Medicine, University of São Paulo from June, 2013 to March, 2016.

Of the 169 appointments, 13 patients were no longer registered for the service, eight did not agree to participate in the study, and one was not able to provide a blood sample. Therefore, 147 patients were followed for this study. 
To compare data on the fluctuations in serological test results between $\mathrm{HIV} / \mathrm{HCV}$-coinfected and $\mathrm{HCV}$-monoinfected individuals, we also analyzed data of 22 patients who attended the Hepatitis Laboratory at the Instituto Adolfo Lutz from 2014 to 2016 .

\section{Ethics}

Blood samples were collected only after written consent forms had been signed. This study was approved by the Ethical Committee in Research at the Instituto Adolfo Lutz (CEPIAL \#663.499).

\section{Clinical Samples}

Two tubes containing EDTA were used to collect $4 \mathrm{~mL}$ peripheral blood from each patient. After centrifugation, plasma samples were aspirated, aliquoted into $2 \mathrm{~mL}$ microtubes, and stored at $-20^{\circ} \mathrm{C}$ until further testing.

Two samples were obtained from each patient to detect new infections and fluctuations in serological markers or HCV RNA. The first blood sample collection was conducted between June, 2013 and May, 2014, and a second collection was performed between November, 2014 and June, 2015. Of all patients, four showed discordant results; thus, we collected a third sample to confirm their molecular and serological test results.

\section{Hepatitis C Virus Serological Diagnosis}

Serological screening of all blood samples was performed with a commercial Murex ${ }^{\mathrm{TM}}$ anti-HCV-version 4.0 kit (Murex Biotech SA, Johannesburg, Republic of South Africa) registered and approved by the Brazilian Ministry of Health.

\section{Hepatitis C Virus Molecular Diagnosis}

All blood samples were analyzed with real-time (RT) polymerase chain reaction (PCR) using the Abbott Real Time $\mathrm{HCV}^{\mathrm{TM}}$ assay (Abbott Molecular, Des Plaines, USA), regardless of serology results. This enabled us to detect both serological and occult infections. Samples testing positive in the quantitative assay were also submitted to in-house RT-PCR for the characterization of viral genotypes.

Genotyping was performed by comparing the alignment of the amino acid sequences with known HCV genotype sequences in GenBank. The Sequence Scanner Software (Applied Biosystems $^{\mathrm{TM}}$, Foster city, USA) was used for these analyses. Genotype classifications were confirmed by the genotyping tool available on the NCBI website (http://www.ncbi.nlm.nih.gov/ projects/genotyping/formpage.cgi).

\section{Analysis of Medical Records}

The medical records of all patients were analyzed to obtain the CD4 lymphocyte values, $\mathrm{HCV}$ and HIV viral load, and HCV serological tests needed for the analyses.

\section{Statistical Analysis}

For statistical analyses, was used the Statcalc tool available in the program EpiInfo for Windows, version 6.04. Results with a $p$-value of $<0.05$ were considered statistically significant.

\section{RESULTS}

One hundred and forty-seven patients [ $95 \mathrm{men}(65 \%)$ and 52 women (35\%)] were recruited on the date of their appointment at the SEAP. The predominant age group was 50-59 years (46\%).

From the 147 patients, 133 (90\%) had CD4 T-lymphocytes $>350$ cells $/ \mathrm{mm}^{3}\left(\mathrm{CD} 4\right.$ mean $=676$ cells $\left./ \mathrm{mm}^{3}\right) ; 26$ patients showed detectable HIV viral load, > 40 copies/mL (VL mean 99103 copies $/ \mathrm{mL}$ ) and 121 patients (82\%) had HIV viral load $<40$ copies $/ \mathrm{mL}$.

Of all patients, $13.6 \%(20 / 147)$ had been exposed to the $\mathrm{HCV}$ virus and 9.5\% (14/147) exhibited an HCV viral load in at least one of the samples.

Discordant serological results were observed for four patients $(20 \%)$ with fluctuations in $\mathrm{HCV}$ serology (Figure 1). These patients exhibited varying reactive, nonreactive, or indeterminate results during follow-up at the service. In contrast, no changes in anti-HCV serological markers were observed in HCV-monoinfected patients. The differences between results obtained from monoinfected and coinfected patients were statistically significant $(\mathrm{p}=0.02)$. No detectable $\mathrm{HCV}$ viral load was found in any of the samples or previous examinations for these patients.

Patients with fluctuations in results showed high levels of CD4 T-lymphocytes $\left(\right.$ mean $=470.5$ cells $\left./ \mathrm{mm}^{3}\right)$ and undetectable HIV viral load $(<40$ copies $/ \mathrm{mL})$.

The log values of the viral load averages of all positive samples from the first and second collections were 5.92 and 5.74 , respectively. We did not observe any significant changes in viral load values in the patients; i.e., patients did not have a variation $>1 \log 10$ during the $\mathrm{HCV}$ viral load quantification.

Of the 14 samples with HCV-positive viral load, genotyping by sequencing could only be performed for 13 samples because of low viral load in the other samples. The predominant HCV genotype was 1a $(69 \%, 9 / 13)$, followed by genotypes 3a $(23 \%, 3 / 13)$ and $2 \mathrm{~b}(8 \%, 1 / 13)$.

\section{DISCUSSION}

Serological and rapid tests are the most commonly used tools to screen individuals for $\mathrm{HCV}$ infection. Third-generation $\mathrm{HCV}$ enzyme immunoassays use recombinant antigens from the core regions (NS3, NS4, and NS5) of the viral genome. These assays allow for the detection of HCV antibodies about 4 to 6 weeks after infection and have a specificity and sensitivity of $>99 \%{ }^{7}$. However, the performance of these tests depends on the levels of antibodies in the serum or plasma of the patient. Therefore, antibodies, although present, might not be accurately quantified due to their concentration being below the detection limit of the test being used ${ }^{8}$.

In this study, we observed fluctuations in the serology results of several serum samples although the patients did not present immunodeficiency and had CD4 T-lymphocyte values within normal parameters. These patients showed reactive, nonreactive, and indeterminate episodes during different analyses, even for very short intervals between sample collections. It is important to emphasize that these patients had never undergone 


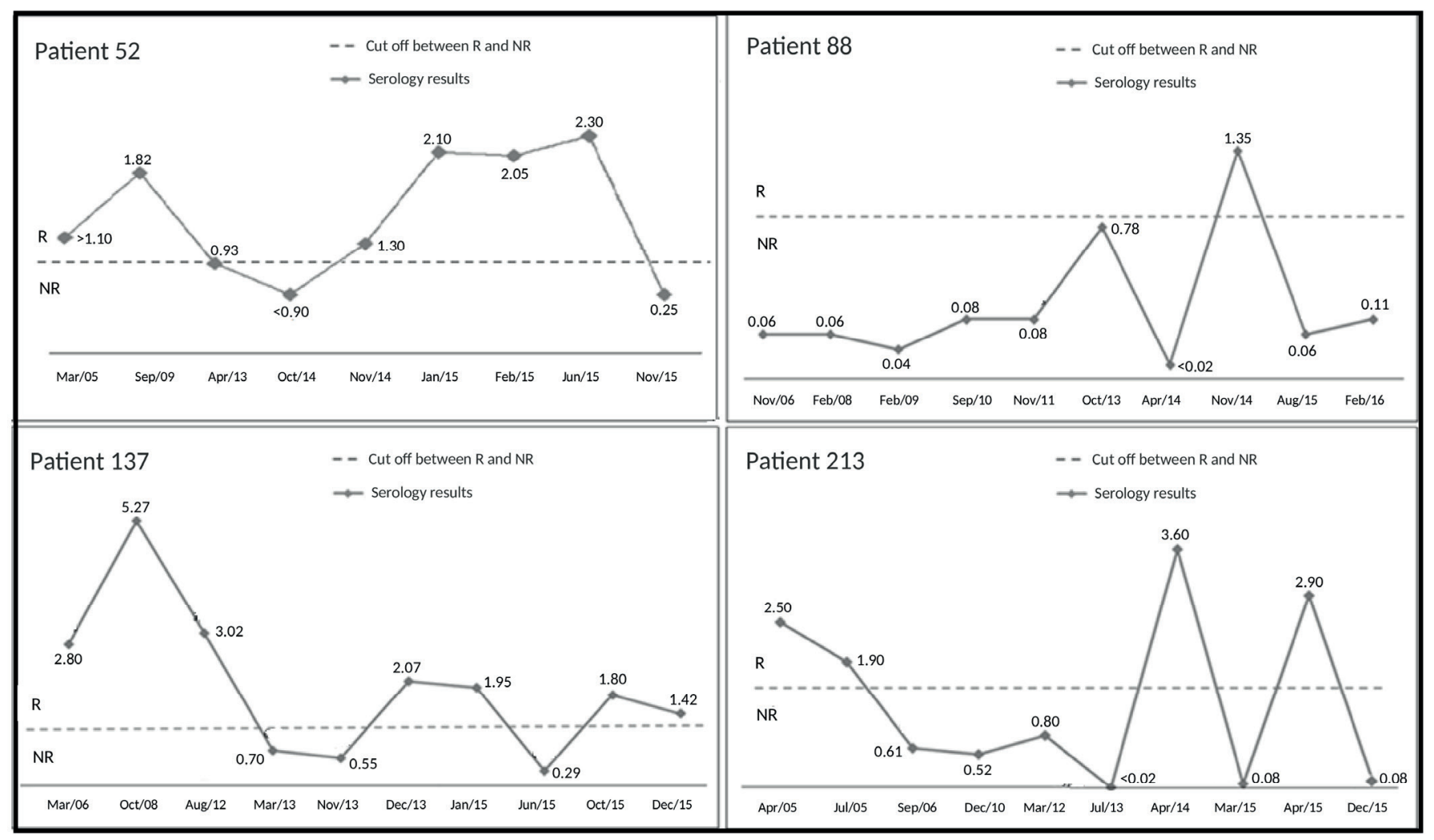

FIGURE 1: Representation of optical density of ratios of each sample based on the manufacturer's cut off (10\%). The dashed line represents OD/CO=1. Values between 0.90 and 1.10 are considered indeterminate. Values $>1.10$ are considerate reactive $(\mathbf{R})$ and values $<0.90$ are considerate not reactive (NR).

treatments for hepatitis $\mathrm{C}$. To the best of our knowledge, this is the first report describing the possibility of serological fluctuations in HCV test results in HIV patients.

Fluctuating serological profiles are commonly found in immunosuppressed patients. According to Moreira and MendesCorrêa, immunosuppression can alter the concentration of total antibodies, preventing them from being detected in serological tests ${ }^{9,10}$; however, in our study, the HIV infection was well-controlled.

Serological and virologic tests are essential to diagnose $\mathrm{HCV}$ infections. Virologic tests include molecular assays that detect and quantify HCV RNA and can be used to determine the HCV genotype ${ }^{11}$. Primary HCV infection may not always elicit $\mathrm{HCV}$ antibodies, suggesting that persistently low levels of HCV RNA might be associated with absent or delayed antibody responses. Therefore, serological tests can show false positive or negative results despite improved sensitivity and specificity. When serology shows false negative or positive results, patient monitoring is compromised ${ }^{7,12}$. In this study, we found no changes in serological markers in $\mathrm{HCV}$-monoinfected patients. This is an important finding because it shows that fluctuation does not commonly occur for the anti-HCV marker.

In the present study, the prevalence of $\mathrm{HCV}$ exposure in HIV patients was $13.6 \%$. Importantly, it has been shown that $\mathrm{HIV} / \mathrm{HCV}$ coinfection is associated with a worse progression to severe liver disease and is considered one of the major causes of death in HIV patients. Moreover, coinfection can increase the risk of transmission of hepatic diseases ${ }^{10}$. Mendes-Corrêa observed a prevalence of HCV/HIV co-infection of $17.7 \%$ in 1457 HIV patients that was much higher than the prevalence among blood donors or other population studies in Brazil ${ }^{13}$.

In this study, we found the highest prevalence of $\mathrm{HCV}$ among men aged 50-59 years. The 2017 STD/AIDS and Viral Hepatitis Epidemiological Bulletin of the Brazilian Ministry of Health in 2016 reported the highest prevalence of HCV infection in patients aged 55-59 years. ${ }^{6}$ The occurrence of $\mathrm{HCV}$ infection in this age group can be explained by the lack of previous regulation such as sterilization of materials, lack of HCV screening at blood banks, lack of screening of risk groups, non-use of condoms, and HIV infection ${ }^{14}$.

$\mathrm{HCV}$ genotyping is important not only to provide epidemiological data but also to help physicians choose adequate medications and decide on the ideal time of administration. In the present study, the most commonly identified HCV genotype was genotype $1(69 \%)$, followed by genotypes $3(23 \%)$ and 2 $(8 \%)$. Similar data were reported by other studies ${ }^{15,16}$.

Patients with positive HCV viral loads (14/147) did not exhibit significant changes in the log between the collection periods. A total of 3/14 patients had CD4 T-lymphocyte counts $<350$ cells $/ \mathrm{mm}^{3}$, which is considered an important factor for HCV progression in HIV patients ${ }^{17,18}$.

Dieterich showed that HIV/HCV coinfection is likely deleterious for both conditions. HIV infection is an important 
cofactor for the progression of liver disease caused by HCV, increasing viremia and accelerating progression to cirrhosis. On the other hand, HCV appears to accelerate the progression of HIV infection, resulting in increased viral load and reduction of CD4 T-lymphocytes ${ }^{19}$. In this study, no significant correlation between HCV viral load and CD4 T-lymphocyte count was observed. However, all patients used antiretroviral drugs at the time of sample collection, explaining the regulation of their HIV infection and consequent maintenance of their immune system.

In this study, 30\% (6/20) of HCV-infected patients with resolved infection were detected. Data on the natural history of HCV infection have shown that about $15-20 \%$ of HCV patients with acute hepatitis $\mathrm{C}$ could recover with no risk of chronic disease $^{20,21}$.

Previous studies have indicated that the prevalence of $\mathrm{HCV} /$ HIV coinfection might be underestimated due to serological fluctuations in HIV patients or due to spontaneous viral bleaching $^{22,23}$. In this study, four patients showed fluctuations in serology. All four had at least one positive result, and all results showed undetectable viral loads. In patients showing fluctuations in serology, physicians cannot determine the infection status of the individual; hence, diagnostic testing must be repeated. Inconsistent test results might affect the follow-up of these patients. Figure 1 shows the results of the serological fluctuations for these patients. In these patients, although positive HCV test results were observed, they could not be confirmed in follow-up tests; such a variation in serological results can hamper clinical decision-making. Serological fluctuations could have been due to errors in the patients' medical records or the use of low-quality serological kits. Fluctuating test results should be interpreted with caution; the quality of the diagnostic kits, the technical analysis, and the period of sample collection should always be analyzed.

This study revealed the presence of fluctuations in HCV serological test results in HIV patients. Our findings highlight the difficulty of following up these patients, as they are often screened using a single serological test that can show false negative or positive results. The effectiveness of serological and molecular tests employed together in the diagnosis of $\mathrm{HCV}$ infection in HIV patients should be implemented for screening new patients and for following them up. Serological data are likely not sufficient to make an accurate diagnosis, and health services and epidemiological surveillances should be alerted. Based on our data, HIV patients should be monitored periodically during subsequent consultations to verify the presence of HCV RNA and the maintenance of reactive serology. Thus, combining serological and molecular assays is likely the best approach to evaluate $\mathrm{HCV} / \mathrm{HIV}$-coinfected patients to reduce the risk of spreading $\mathrm{HCV}$, as these assays likely have a synergistic effect ${ }^{9}$.

\section{Acknowledgements}

We are grateful to the SEAP team and IAL virology laboratory for their assistance and excellent work in the execution of this research.

\section{Conflict of Interest}

The authors declare that there is no conflict of interest.

\section{Financial Support}

This work was supported by the Coordination of Improvement of Higher Level Personnel (CAPES).

\section{REFERENCES}

1. Martins T, Schiavon N, Luz J, de Lucca L. Epidemiologia da infecção pelo vírus da hepatite C. Rev Assoc Med Bras. 2011;57(1):107-112.

2. World and Health Organization (WHO). Hepatitis C. 2017. Available at: <http://www.who.int/mediacentre/factsheets/fs164/ en/>. Accessed on: 03 Ago. 2017.

3. Pereira LMMB, Martelli CMT, Moreira RC, Merchan-Hamman E, Stein AT,Cardoso MRA, Figueiredo GM, et al. Prevalence and risk factors of Hepatitis C virus infection in Brazil, 2005 through 2009: a cross-sectional study. BMC Infect Dis. 2013;13:60.

4. Ministry of Health (MS). Clinical Protocol and Therapeutic Guidelines for Viral Hepatitis C and Coinfections. Brasília - Df, 2017; 109 p. Available at: <http://conitec.gov.br/images/Consultas/2017/ Relatorio_PCDT_HepatiteCeCoinfeccoes_CP11_2017.pdf $>$. Accessed on: 01.out.2017.

5. Wolff FH, Fuchs SC, Barcellos NN, de Alencastro PR, Ikeda ML, Brandão $\mathrm{AB}$, et al. Co-infection by hepatitis $\mathrm{C}$ virus in People living with HIV patients in southern Brazil: genotype distribution and clinical correlates. PLoS One. 2010;5(5):e10494.

6. Ministry of Health (MS). Epidemiological Bulletin - Viral Hepatitis. Brasília - DF, 2017. 68p. Available at: http://www.aids.gov.br/ptbr/pub/2017/boletim-epidemiologico-de-hepatites-virais-2017. Accessed on: 03.out.2017

7. Villar LM, Cruz HM, Barbosa JR, Bezerra CS, Portilho MM, Scalioni LP. Update on hepatitis B and C virus diagnosis. World J Virol. 2015;12:4(4):323-42.

8. Easterbrook PJ, Roberts T, Sands A, Peeling R. Diagnosis of viral hepatitis. Curr Opin HIV AIDS. 2017;12(3):302-14.

9. Moreira RC, Pinho JR, Fares J, Oba IT, Cardoso MR, Saraceni CP, et al. Prospective study of hepatitis $C$ virus infection in hemodialysis patients by monthly analysis of HCV RNA and antibodies. Can J microbiol. 2003;9(8):503-7.

10. Mendes-Corrêa MCJ, Barone AA, Cavalheiro N de P; Tengan, FM, Guastini C. Prevalence of hepatitis B and C in the sera of patients with HIV infection in São Paulo, Brazil. Rev Inst Med Trop. 2000;42(2):81-5.

11. Chevaliez S, Pawlotsky JM. Hepatitis C Virus Serologic and Virologic Tests and Clinical Diagnosis of HCV. Int J Med Sci. 2006;3(2):35-40.

12. Beld M, Penning M, Van Putten M, Van Den Hoek A, Damen M, Klein MR, et al. Low levels of hepatitis C virus RNA in serum, plasma and peripheral blood mononuclear cells of injecting drug users during long antibody-undetectable periods before seroconversion. Blood. 1999;94(4):1183-91.

13. Mendes-Corrêa MC, Barone AA, Guastini C. Hepatitis C vírus seroprevalence and risk factors among patients with HIV infection. Rev Inst Med Trop Sao Paulo. 2001;43(1):15-9.

14. Busch MP, Kleinman SH, Nemo GJ. Current and emerging infectious risks of blood transfusions. JAMA. 2003;289(8):959-62.

15. Martins RMB, Teles AS, Freitas NR, et al. Distribution of hepatitis $\mathrm{C}$ virus genotypes among blood donors from mid-west region of Brazil. Rev Inst Med Trop Sao Paulo. 2006;48(1):53-5.

16. Carvalho AC, Junior JLP, Silva MFO, Neto SGS. Perfil genotípico da hepatite $\mathrm{C}$ em um laboratório público do estado do Piauí. $\mathrm{R}$ Interd. 2014;7(3):55-60. 
17. Sabin CA, Telfer P, Phillips NA, Bhagani S, Lee CA. The association between hepatitis $\mathrm{C}$ virus genotype and human immunodeficiency virus disease progression in a cohort of hemophilic men. J Infect Dis. 1997;175:164-8.

18. Sulkowski MS, Mast EE, Seeff LB, Thomas DL. Hepatitis C virus infection as an opportunistic disease in persons infected with human immunodeficiency virus. Clin Infect Dis. 2000;30(Suppl 1):S77-84.

19. Dieterich DT. Hepatitis $C$ virus and human immunodeficiency virus: clinical issues in co-infection. Am J Med. 1999;107:79-84.
20. Afdhal NH. The natural history of hepatitis C. Sem Liver Dis. 2004;24(suppl 2):3-8.

21. Hoofnagle JH. Course and outcome of hepatitis C. Hepatol. 2002;36(supl 1):21-29.

22. Spengler U, Rockstroh JK. Hepatitis $C$ in the patient with human immunodeficiency virus infection. J Hepat. 1998;29(6):1023-30.

23. Zylberberg H, Pol S. Reciprocal Interactions Between Human Immunodeficiency Virus and Hepatitis C Virus Infections. Clin Infect Dis. 1996;23(5)1117-25. 